\title{
Reading Derwent Water in Literature and Painting: From John Brown to Chiang Yee
}

\author{
Jingdong Zhong \\ English Faculty, Zhejiang Yuexiu University of Foreign Languages, Shaoxing, China
}

\section{Email address:}

1755516968@qq.com

\section{To cite this article:}

Jingdong Zhong. Reading Derwent Water in Literature and Painting: From John Brown to Chiang Yee. International Journal of Literature and Arts. Vol. 4, No. 5, 2016, pp. 84-89. doi: 10.11648/j.ijla.20160405.15

Received: September 29, 2016; Accepted: October 18, 2016; Published: October 20, 2016

\begin{abstract}
This paper attempts to discuss the ways of examining visual and verbal representations of landscapes so as to strengthen the "self-knowledge" of adjusting the balance between human beings and nature. Through reading Derwent Water in literature and painting, the paper has a short study on the process of making a wonderful landscape, which is focused on the amphitheatre of the lakescape, Lodore and the scenery after sunset. The study confirms that the popularity of Derwent Water mainly lies in its terrific landscape concerned with an interwoven history of visual and verbal representations, the reading of which can lead to a deepening love and respect for our natural heritage and might also help to "see" the unseen human harms done to the landscape nowadays.
\end{abstract}

Keywords: Derwent Water, Literature and Painting, Amphitheatre, Lodore, The Scenery After Sunset

\section{Introduction}

During a mountain night-walking in a marathon year of this century, photographer Henry Iddon perched on fell tops and took a set of "rare" pictures of Keswick and Derwent Water. One of them was taken from the slopes of Skiddaw at $11.22 \mathrm{pm}$, in which "bright clusters of streetlamps and house lights dot the unusual images of the lakescape" with the bright orange glow contrast to the night sky and thus revealed "the imprint of man's high carbon lifestyles" and charted the effects of light pollution on the wild lakeland: "As well as depriving people of the stars at night, this obvious light is a sign of the needless damage man is doing to the environment." [1] This leads to the meditations "on the relationship of reverence and of interdependence that we ought to foster with the natural world around us." [1]

"Interaction with landscape," which basically prefers "an unquivering poise and peace," can "heal you if you respect it," however, it "can also return its pain to you if you abuse or damage it." [2] Unfortunately, as in the case of Derwent Water, the peace is being broken by too much human interference such as light pollution and once a harmonious interaction is becoming more and more unsatisfactory. To "become aware of our stage of 'becoming,", "we need to look back at our history" of making a landscape, [2] whose "scenery is built up as much from strata of memory as from layers of rock." [3] Such "strata" is composed of a variety of materials including literary texts and paintings, since in the process of landscaping "the meanings of verbal, visual and built landscapes have a complex interwoven history." [4]

Basically, this paper attempt to discuss the ways of "digging down through layers of memories and representations" to strengthen the "self-knowledge" of adjusting the balance between human beings and nature, [3] with the case study of reading Derwent Water represented in literature and painting.

\section{Setting the Scene}

\subsection{Mapping the Physical Landscape of Derwent Water Briefly}

In terms of geomorphology, the whole English Lake District can be seen as a discrete area of small mountains in the northern part of England, which is divided into narrow valleys, many with lakes framed by fells that, as Wordsworth said, diverge like "the spokes of a wheel from a hub somewhere between Great Gable and Scafell," and the last "spoke" of this wheel is Borrowdale, of which "the vale of Keswick is only a continuation, stretching due north" from 
the head of Derwent Water. [5] This lake is generally referred to as the Queen of the English Lakes and has long been a favourite of visitors to the Lake District. From 3 to 7 October in 1769, Thomas Gray (1716-1771) stayed at the Queen's Head in Keswick, using it a base for excursions. It's here that William Gilpin (1724-1804) "resolved to fix" the "head-quarters for a few days; and from thence to visit such of the neighbouring lakes, and mountains, as had been most recommended" to the notice, and as he stated: "Of all the lakes in these romantic regions," Derwent Water "seems to be most generally admired." [6] It attracted the foreign visitors as well, for instance, during his twelve days' stay at the Lake District in the summer of 1936, a Chinese artist, Chiang Yee (1903-1977) spent much time (including seven nights) at Derwent Water and still wished to stay longer.

The popularity of Derwent Water lies in at least two factors. Firstly, it has a strategic position, for from here it is easy to reach other lakes, among which Bassenthwaite Lake is just a few miles north, while Ullswater to the east is conveniently also reached, and going south via St. Johns Vale is Grasmere and Rydal which lead to Windermere. Secondly, its terrific landscape, including the water's own beauty and its use in composition, arrives at a state of "full perfection," [7] thus making it a preferable object represented frequently in literature and painting which combined to create a cultural landscape with much "strata of memory."

\subsection{Sketching Representations of Derwent Water}

As the first tourists to Derwent Water, both Dr. John Brown (1715-1766) and John Dalton (1709-1763) wrote works in praise for the magnificent scenery of Derwent Water. The former, who had grown up in Cumberland in the 1750s, described "the vale and lake of Keswick" in a letter: "The full perfection of Keswick consists of three circumstances, beauty, horror, and immensity united... But to give you a complete idea of these three perfections, as they joined in Keswick, would require the united powers of Claude, Salvator[Rosa], and Poussin." [7] The latter, who also originally from Cumberland, wrote in 1755 an impressive poem enumerating the beauties of Derwent Water: "Horrors like these at first alarm, / But soon with savage grandeur charm, / And raise to noblest thoughts the mind." [7] Their zeal encouraged other persons to visit the district.

Gray was one of such followers, who read and admired both Brown and Dalton and toured the lakes in 1769. Then he published an account of his five-day stay there, which was widely read, and was, in Bott's phrase, "an effective public relations job for Keswick." [8] As Gray's literary executor and first biographer, William Mason (1724-1797) actually toured the lakes with Gray's journal in hand. However, with some unsatisfaction he uttered his complaints about the lack of combining illustrations and descriptions. On 13 June 1772, he wrote to William Gilpin: "I assure you I think they [sketches and descriptions] give the most satisfactory idea that can be, where verbal ones are never sufficient for me insomuch that tho' I have Mr Gray's account of the tour by me at present, I find a constant want of accompanying sketches," and on 23 August 1774, he wrote to Gilpin again: "Mr Gray, who as much power of words as any man with as much so election also wanted you power of pencil, and I am convinced that they must go together to convey a true idea of the place they are employed to describe." [9] Anyhow, when Mason privately printed Gray's journal in 1775 as the editor himself, he didn't settle such complaints.

In fact, there was no shortage of "power" of representing the lakes through visual art even from the very beginning. Some painters such as Thomas Smith of Derby $(-1767)$ and William Bellers (1749-1773) toured the lakes almost at the same period of time when Brown and Dalton took their visits They also contributed to the influx of visitors through engravings of their paintings of Cumberland scenery, one of which by Smith (see Figure 1) was most famous and sold in large numbers. However, Joseph Farington RA (1747-1821) was perhaps the first person who attempted to combine the power of visual and verbal creations "to convey a true idea" of the lakes. As a great admirer of Gray and early possessor of the 1775 edition of his writings edited by Mason, Farington toured the lakes twice, painting views that Gray would have seen. Anyway, the works by Farington and Gray can only be combined in a book edited by John R. Murray till

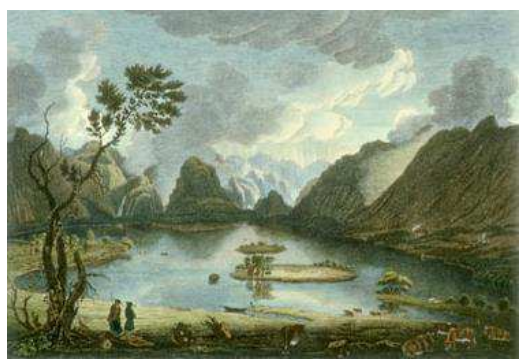

Figure 1. A View of Derwentwater etc. from Crow-Park. [10]

2011. Although "the end of the eighteenth century saw visitors to the lake increasing, and by 1790 s Keswick had become a centre for 'tourists'," [9] the lack of the combination of images and words was still common in popular guide books, including one of two bestselling guides to the lakes by Thomas West (1720-1779). As for the other, Gilpin's guide, it attempted to juxtapose some pen-and-wash drawings and the descriptions by Gilpin himself, which seemed not yet "to go together to convey a true idea" due the fact that the drawings were too sketchy. At least one thing unsatisfactory concerning Gilpin's visual representations was that "he never ascends to the top of a mountain, and if he gets up higher than usual, he merely says that the view is grand and amusing, as if because it was not easy to paint." [11]

Such a challengeable job also confronted a 1810 book of lake engravings entitled as Select Views in Cumberland, Westmoreland, and Lancashire, with a prose companion written by William Wordsworth (1770-1850), who was unsatisfied with his own writings and even published it anonymously. Wordsworth has strived for the improvement of the words with several updated versions. As for the the painter's "disgust" images, he cut off them with his writing ever since the 1822 version of his Guide to the Lakes. This 
might reveal a view of disapproval towards average western painters, one of whom, a female English artist once talked with Chiang Yee at Derwent Water, who "always preferred to paint with her eyes on the scenery" due to the fallibility in "the power of memorising objects" while Chiang could turn to such a power to keep "the whole panorama of Derwent Water" in his "mind's eye" and then painted a long roll (See Figure 2), "showing the scenery of the whole lake". [12]

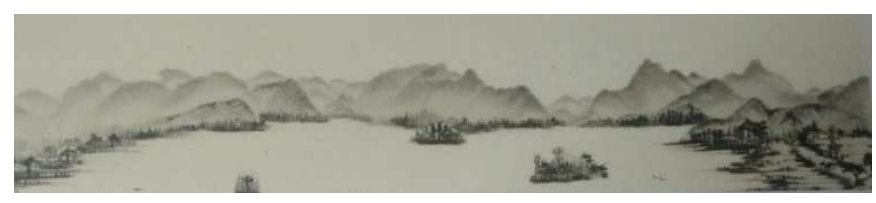

Figure 2. The Charm and Gentleness of Derwent Water. [12]

The next two sections will do a further study on how Derwent Water was observered and represented in the works of writers and artists from John Brown to Chiang Yee, which were concerned with the panorama and two featured views of the lakesape.

\section{Reading the Amphitheatre of Derwent Water in Literature and Painting}

\subsection{The Amphitheatre of Derwent Water in the Eyes of the Earliest Tourists}

In his letter concerning Derwent Water, Brown started his describing with the comparison of Doverdale and Keswick, which emphasized the advantages of the latter from the perspective of a panorama: "Instead of the narrow slip of valley which is seen at Dovedale, you have at Keswick a vast amphitheatre, in circumference above twenty miles." [7] As a prefix occurring in loan words from Greek (amphibious), "amphi-" is used with the meaning "on both sides" which denoted "around" later in old English and the word of "amphitheatre" denotes "a level area of oval or circular shape surrounded by rising ground" as well as "a building with tiers of seats around a central area." [13] It is "an open space that is surrounded by high land in a circular slope" as well as "a circular building without a roof and with rows of seats that rise in steps around an open space." [14] The landscape of Derwent Water was really featured in the form of an amphitheatre as Brown furthered to state. "Instead of a meagre rivulet," the water was "a noble living lake, ten miles round, of an oblong form, adorned with a variety of wooded islands," and "on all sides of this immense amphitheatre, the lofty mountains rise round, piercing the clouds," in "spiry, fantastic" shapes. When remarking "the contrast of light and shade, produced by the morning and the evening sun," Brown also set it in "this immense amphitheatre," in which the eastern and western sides of which two suns glided respectively. [7] Besides, in order to intensify the effects of such a general view, Brown finally "guided" his friend to the top of a cliff, where "the valley, lake, and islands seem lying at your feet," and the lake "appears diminished to a little pool, amidst the vast immeasurable objects that surround it," and with the presentation of "the image of a tempestuous sea of mountains," the drama the lakescape seemed to arrive at the climax. [7]

Among painters whose work consisted largely of Lake District views, Beller was the first to try to catch such a drama of the lakescape with the prints of the great circle of mountains surrounding Derwent Water. Probably, due to such a style, his work helped a direct fashionable taste towards the area in connection with the popular picturesque landscape of the 18th century. Meanwhile, other artists leant more to the sublime and the quest for it often led them "to exaggerate, making the fells almost unrecognisable", and as one of such artist, Smith once drew a picture concerning Derwent Water (See Figure 1) that was "almost like a Chinese painting," in which the mountains "soar straight up from the lakes into zig-zag summits," "complete with billowing storm clouds and blasted tree" above and in front respectively. [15] It enjoyed the same composition as Beller's, placing the lake in the center of the picture which was surrounded by a range of peaks. Gray showed his appreciation for Smith's creation, considering he "judged right when he took his print of the lake from hence, for it is a gentle eminence, not too high, on the very margin of the water, and commands it from end to end, looking full into the gorge of Borrowdale." [9]

This kind of amphitheatre-like view was adopted in other creations by the persons who followed the suit, including a Chiang Yee's long roll (See Figure 2), whose view was basically concerned with the east side of the lake as many others were. This kind of view will be discussed in the next section.

\subsection{The Amphitheatre of Derwent Water Along the East Side in the Eyes of Tourists}

Having toured around the lake, Glipin showed his preference for the east side, on which "the mountains are both grander, and more picturesque. The line is pleasing; and is filled with that variety of objects, broken-ground, -rocks, and wood, which being well combined, take from the heaviness of a mountain; and give it an airy lightness." [6] He chose this rout to Borrodale, "skirting the eastern coast along the edge of the water," and the scenes along this side further confirmed it as a right choice. Finding the rocky shores "every where" were the happiest stations for obtaining the most picturesque views of the lake," he argued that an inexperienced conductor might carry people "to some garish stand, where the eye may range far and wide" and "such a view is well calculated" to "obtain a general idea of the whole," however, "he, who is in quest of the picturesque scenes of the lake, must travel along the rough side-screens that adorn it; and catch it's beauties, as they arise in smaller portions." [6]

Such a preference of the east side was echoed in works by West and Farington, for three stations around the Derwent Water chosen as the best viewpoints by the former (the citations of them in the subsequent discussion are identified by the initial "W," followed by the station number in the 
book ) and three paintings by the latter included in the book edited by Murray (the citations of them in the subsequent discussion are identified by the initial "F," followed by the picture number in the book ) were all concerned with the east side.

\subsection{1. $W 1+W 2+F 3$}

West set his first station to obtain the best views at Cockshut-hill, considering that it "is remarkable for a general view" and from it "the lake appears in great beauty," and described Derwent Water vividly as "an elegant sheet of water," which lay on the floor of "a spacious amphitheatre of the most picturesque mountains imaginable," and owing to the reflecting property of the lake which was set in a amphitheatre, there were "amazingly great" effects all around "when the sun plays upon the bosom of the lake: The surrounding mountains are illuminated by his refulgent rays, and their rocky broken summits invertedly reflected by the surface of the water." [7] As for W2, West first quoted Gray's appreciation for Smith's picture (See Figure 1) concerning Crow-park and showed preference for its view which "is lower and nearer the lake" in comparison to that of Cockshut-hill where "all points that are much elevated, spoil the beauty of the valley, and make its parts, which are not large, look poor and diminutive." [7]

However, Farington seemingly held a different viewpoint and preferred to the view from Cockshut-hill, for it "burst upon the eye with inconceivable splendour, and exhibits the general form of Derwent Water much better, perhaps, than from any other point of view," which can be displayed in F3: "The craggy mountain which first presents itself on the left is known by the name of Wallow Crag," while "the hollow in its crumbling summit is called Lady's Rake. The low mountains in front are Grange Fells, in which Castle-Crag is conspicuous," behind which several crags "successively rear their heads, forming a conspicuous part of Borrodale Fells," and then Causeway Pike and Grisedale Pike close this amphitheatre of mountains, at the foot of which "appears the Lake itself, which is broken into several pretty bays." [9]

\subsection{2. $\mathrm{WB}+\mathrm{F6}+\mathrm{F8}$}

At W3 you can see "Stable-hills on the right; and Wallow-crag directly over you on the left," and it's really a ideal place to view the lake, where "all that is great or pleasing on the lake, all that is grand and sublime in the environs, lie before you in a beautiful order, and natural disposition," to the exclusion of any idea of river or outlet. [7] Looking cross such open water, you can see the much beautiful opposite shore "bounded by a range of hills, down to the entrance of Newland vale" and the north end of the coast "exhibits what is most gentle and pleasing in landscape," and concerning the violent southern extremity of the lake, there is "a forest of broken pointed rocks, in a semicircular sweep, towering inward, from the most horrid amphitheare that ever eye beheld in the wild forms of convulsed nature," and such great scenes "continue to the gorge of Borrowdale" and "Castle-crag may be seen, in the centre of the amphitheatre." [7]

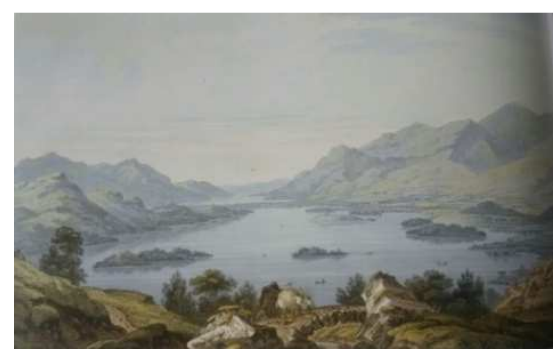

Figure 3. View over Derwentwater to Bassenthwaite Lake. [9]

A little far from W3 is another general view from Ashness revealed in F6 (See Figure 3). It is perhaps the best point "where the several features which distinguish the romantic vale will appear to be so strongly marked," with the elevation "sufficient to command an extensive prospect, without so far reducing its component parts as materially to affect their importance": [9] In front is a great part of Derwent Water with its four islands while in the distance is the Lake of Bassenthwaite. Skiddow rises on the right from the margin of this lake while Newlands and Thornthwaite fells appear on the left. Moving on to Lodore revealed in F8, from which there is also a charming view of an amphitheatre concerning Derwent Water, "with Skiddaw for its background" which "reared his majestic head" and "in the transparent lake, were the three wooded islands." [9]

\section{Reading Two Featured Sceneries at Derwent Water in Literature and Painting}

\subsection{Lodore}

"Lodore Waterfall is generally claimed one of the most striking objects of the kind in this country; its accompaniments are uncommonly picturesque and grand," [9] because in an experience of a waterfall, as the American artist Thomas Cole once stated, we can generally "perceive unceasing change and everlasting duration" which might be naturally related to Niagara where "the sublime and beautiful are bound together in an indissoluble chain," and concerning the sublimity, in its "volume," "course" and "impetuosity" we conceive "immensity," "everlasting duration" and "uncontrollable power" respectively. [16]

Surely, the juxtaposition of a waterfall and a lake would present to the mind the ideas of fixedness and motion simultaneously, with the blending of "savage grandeur charm" and "noblest thoughts" as Dalton stated. So it's easy to understand that how a waterfall contributes to the charms of a featured scenery at Derwent Water. West introduced it as this: "an awful chasm is formed, through which the waters of Watanlath are hurled. This is the Niagara of the lake, the renowned cataract of Lodore." [7] Seeing it, an ingenious person responded naturally with a cry: "Here is beauty indeed--Beauty lying in lap of Horror!" [6] And, perhaps this juxtaposition can persuasively explain Gilpin's comment mentioned before: "Of all the lakes in these romantic regions," Derwent Water "seems 
to be most generally admired." Concerning this wonder, F5 and F7 give a distant view and a close shot respectively.

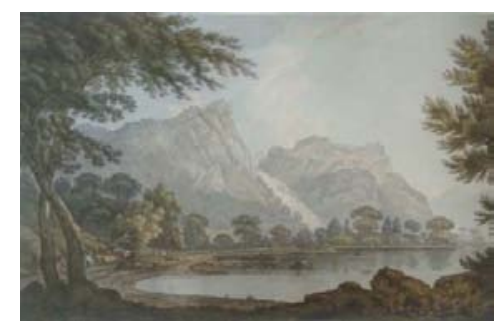

Figure 4. Looking South to Lodore Falls. [9]

The view of F5 (See Figure 4) "is taken is a little to the right of the road leading from Keswick into Borrowdale, near the side of Derwent Water, where it forms a small bay." Standing a little far from the fall, we can see the composition of landscape clearly with the stupendous crags as the figure, which "are shagged with trees hanging everywhere in the most fantastic shapes" and between them "the torrent precipitates itself broken into the boldest form." [9] With a closer view in F7, we can really conceive "immensity," "everlasting duration" and "uncontrollable power" of the fall. When "charged with the thousand streams which a storm pours occasionally from the mountains, the bubbling cascade becomes a stupendous cataract, which, rushing down on an enormous pile of protruding crags, rolls along in uninterrupted volume and impetuous velocity," and if we get closer, a view would be gained "when the whole scene lay open to the eye and the torrents of rain had filled every cavity of the fall, and flooded the brook proceeding from it." [9]

According to Gray: "The height appears to be about 200 feet" and "the force of the water wearing a deep channel in the ground hurries away to join the lake," [9] presenting a terrific scene "combined with unceasing change and everlasting duration" to the mind. Gilpin also paid a attention to the companionship of the fall and the lake as well as the force of the former: Lodore "is a noble object, both in itself, and as an ornament of the lake," which "appears more as an object connected with the lake, as we approach by water," for amongst the ground "the water is swallowed up into an abyss; and at length finds it's way, through deep channels, into the lake." [6] Concerning the force of the water, he observed that the streams fell through a chasm between two towering perpendicular rocks, among which "the stream finds it's way through a fall of at least an hundred feet," which "is every way suited to the grandeur of the scene" in heavy rains. [6]

As a Chinese in England who felt awfully homesick, Chiang Yee made different responses when touring this fall: "As I listened to the roar of the tumbling water I easily imagined myself back in my native land visiting the 'Yellow-Dragon Fall' of Lu mountain," and no matter sitting in the seat provided before the falls or on a large stone in a higher position, he couldn't help recalling the past life and his "mind simply wandered back" to the home. [11] Perhaps such a feeling was prompted by the magic of the fall itself, because as Cole stated, "In gazing on it we feel as though a great void had been filled in our minds-our conceptions expand-we become a part of what we behold!" [16]

\subsection{The Scenery After Sunset}

The scenery after sunset is another featured one at Derwent Water which caught the attentions of the tourists from the very beginning. Let's start the discussion with Dr. Brown again, who concluded his description of the vale and lake of Keswick with a nice "walk by still moonlight (at which time the distant water falls are heard in all their variety sound) among these enchanting dales, opens a scene of such delicate beauty, repose, and solemnity, as exceeds all description." [7]

West accepted Dr. Brown's recommendation that the lake be viewed by moon-light. He also mentioned "the voices of the water-falls" which "are re-echoed from every rock and cavern, in a manner truly singular and pleasing," and then he juxtaposed the setting sun and the rising moon to create a terrific scene, in which the former "tips the mountain's top with the softest refulgence" and the latter "with her silver rays just continues in vision the glories of its base." [7] The surface of the lake was scrutinized with the comparison of its reflections in the daytime and in the moon night. The lake surface "in the day reflects the azure sky, the deep green woods, or hoar-coloured rocks, is now a sable mirror, studded with the reflected gems of the starry heavens" or "a plain on which are penciled by the moon the fair outlines and shadows of the hills behind which she labours," and "all now is in faint light, grave shade, or solemn darkness, which apparently increases the vastness of objects, and enwraps them in a solemn horror that strikes the mind of the beholder with reverential awe, and pleasing melancholy." [7]

Such an atmosphere was no difference from that when Gray "walk'd alone down to the Lake by the side of Crow-Park after sunset \& saw the solemn colouring of night draw on" on the evening of Oct. 4. As Gray observed, "the last gleam of sunshine fading away on the hill-tops, the deep serene of the waters, $\&$ the long shadow of the mountains thrown across them, till they nearly touch'd the hithermost shore," and as for "the murmur of many waterfalls not audible in the daytime," it could be heard at distance now, besides, as one of the fans of the moon, Gray longed to meet it, but he could only sign with great pity, for "she was 'dark to me \& silent, hid in her vacant interlunar cave'." [9]

Ching Yee sighed the same kind of pity as well, which developed into deep sadness since the moon did not come out after his long wait. He described the process of seeking and waiting for the moon in detail as follows:

It was not dark yet. I gazed on the mirror-like surface of the water and listened to the sound of the oars striking it steadily and rhythmically-Once I felt I was ski-ing backwards on ice, and then I was like a dragonfly perching and skimming along the water surface. The mountains on both sides were apparently moving along as well, but showing their friendship to us as if they were coming out to welcome us one after another. There were a few white spots on the water almost out of our sight that I believed were seagulls. It was very quiet, though there were some boats on the lake, but far away from ours. [12] 
He "stayed there on the lake until every other boat had moored up for night, but still there was no moon to be seen." The components included in construing such a peaceful lakescape by Chiang Yee were no difference from those by Brown, Gray and West. In all the descriptions, things like the moon and waterfalls were generally included, which could be summarized in Table 1.

Table 1. Representations of Derwent Water after sunset.

\begin{tabular}{|c|c|c|}
\hline \multirow{2}{*}{ Author } & \multicolumn{2}{|c|}{ Representations of Derwent Water after sunset } \\
\hline & Things mentioned & Description \\
\hline Brown & $\begin{array}{l}\text { Moonlight; } \\
\text { the sound of water falls; } \\
\text { dales }\end{array}$ & $\begin{array}{l}\text { still; } \\
\text { enchanting, delicate beauty, } \\
\text { repose, and solemnity }\end{array}$ \\
\hline Gray & $\begin{array}{l}\text { night; } \\
\text { sunshine; } \\
\text { waters, } \\
\text { shadow of the mountains; } \\
\text { waterfalls; } \\
\text { the moon }\end{array}$ & $\begin{array}{l}\text { solemn; } \\
\text { fading away on hill-tops; } \\
\text { deep serene; } \\
\text { thrown across; } \\
\text { murmur; } \\
\text { dark to me \& silent, hid }\end{array}$ \\
\hline West & $\begin{array}{l}\text { water-falls; } \\
\text { the setting sun; } \\
\text { the rising moon; } \\
\text { the surface of the lake }\end{array}$ & $\begin{array}{l}\text { re-echoed; } \\
\text { tips the mountain's top; } \\
\text { with silver rays } \\
\text { mirror, plain; } \\
\text { All is in faint light, grave shade, or } \\
\text { solemn darkness. } \\
\text { a solemn horror, reverential awe, } \\
\text { pleasing melancholy }\end{array}$ \\
\hline Chiang & $\begin{array}{l}\text { surface of the water; } \\
\text { the sound of the oars; } \\
\text { mountains; } \\
\text { seagulls; } \\
\text { the moon }\end{array}$ & $\begin{array}{l}\text { mirror-like; } \\
\text { steadily and rhythmically; } \\
\text { moving along; } \\
\text { white spots on the water; } \\
\text { very quiet; } \\
\text { not to be seen, sadness }\end{array}$ \\
\hline
\end{tabular}

\section{Conclusion}

Through examining combined materials of visual and verbal materials concerning Derwent Water, this paper has a short study on the process of making such a cultural lakescape. The study starts with mapping the physical landscape of the lake briefly, considers two factors that contribute to its popularity, i.e. a strategic position and a terrific landscape including the water's own beauty and its use in composition. In sketching representations of the lake in general, several main figures in the field of literature and painting are involved, such as Brown, Dalton, Gray, Smith, Farington, West, Gilpin, Wordsworth and Chiang Yee, and the issue of image-word representations is particularly considered. Then this paper further discusses the representations of concrete landscapes of the Derwent Water concerning the amphitheatre of the lake, Lodore and the scenery after sunset.

As the relative literary texts and paintings represent, the amphitheatre of the lake conveys a spacious view with pleasant points where the whole may be seen at once, drawing an observer's attentions inward to a single focus, and thus achieves a sense of union or oneness, while the juxtaposition of a waterfall and a lake would present to the mind the ideas of fixedness and motion simultaneously, which contributes to the making of a colorful and charming landscape. As for the scenery after sunset, with some nice components such as moonlight and murmuring waterfalls, they are helpful to achieve a peaceful mind. In short, reading such landscapes in literature and painting can lead to a deepening love and respect for our natural heritage and might also help to "see" the unseen human harms done to the landscape nowadays.

\section{References}

[1] M. Wainwright, "Photos by night illuminate Lake District light pollution," Retrieved from https://www.theguardian.com/environment/2008/jul/14/energy .carbonfootprints

[2] J. O'Donohue, The Four Elements: Reflections on Nature. London: Transworld Ireland, 2010, xiv, xvi.

[3] S. Schama, Landscape and Memory. London: Fontana Press, 1996, pp. 7, 16-18.

[4] D. Cosgrove and S. Daniels, Eds, The Iconography of Landscape. New York: Cambridge University Press, 1988, pp. 1.

[5] W. Wordsworth, Guide to the Lakes, 1835. Retrieved from http://www.rc.umd.edu/editions/guide_lakes/editions.2015.gui de_lakes.1835.html.

[6] W. Gilpin, Observations, Relative Chiefly to Picturesque Beauty, Made in the Year 1772, on Several Parts of England: Particularly the Mountains, and Lakes of Cumberland, and Westmoreland. Volume 1. New York: Cambridge University Press, 2013[1786], pp. 177, 182-186, 191.

[7] T. West, A Guide to the Lakes in Cumberland, Westmoreland, and Lancashire. By the Author of the Antiquities of Furness. The Tenth Edition. London: British Library, 1812, pp. 85-90, 112. 193-198.

[8] G. Bott. Keswick-The Story of a Lake District Town. Carlisle: Cumbria County Library, 1994, pp. 39.

[9] J. R. Murray, A Tour of the English Lakes: With Thomas Gray and Joseph Farington, R.A. London: Frances Lincoln, 2011, pp. $19,28,36,38,84,90-94$.

[10] Thomas Smith (of Derby). "A View of Derwentwater etc. from Crow-Park," Retrieved from

http://webarchive.nationalarchives.gov.uk/+/http://www.gac.c ulture.gov.uk/search/Object.asp?object_key=21183

[11] People of Cape Cod and Walden: The Reverend William Gilpin, Retrieved from

http://www.kouroo.info/kouroo/thumbnails/G/WilliamGilpin.pdf.

[12] Chiang Yee, The Silent Traveller in Lakeland. Edinburgh: Mercat Press Ltd, 2004[1937], pp. 34, 44, 47-48.

[13] Webster's Encyclopedic Unabridged Dictionary of the English Language. Avenel: Gramercy Books, 1996, pp. 50.

[14] Oxford Advanced Learner's Dictionary, 6th ed. Oxford: Oxford University Press, 2000, pp. 38.

[15] J. Uglow, "A passion for painting in the Lake District," Retrieved from https://www.theguardian.com/artanddesign/2011/may/14/paint ings-lake-district-jenny-uglow

[16] T. Cole, "Essay on American Scenery," American Monthly Magazine, No. 1, 1936, pp. 1-12. 